\title{
Correction: Identification of specific calcitonin-like receptor residues important for calcitonin gene-related peptide high affinity binding
}

\author{
Sugato Banerjee $^{1}$, Janel Evanson ${ }^{1}$, Erik Harris ${ }^{1}$, Stephen L Lowe ${ }^{2}$, \\ Robert C Speth ${ }^{3}$, Kathryn A Thomasson ${ }^{2}$ and James E Porter*1
}

Address: ${ }^{1}$ Department of Pharmacology, Physiology \& Therapeutics, School of Medicine \& Health Sciences, University of North Dakota, Grand Forks, ND 58202-9037, USA, 2Department of Chemistry, University of North Dakota, Grand Forks, ND 58202-9024, USA and ${ }^{3}$ Department of Pharmacology, School of Pharmacy, University of Mississippi, University, MS 38677-9802, USA

Email: Sugato Banerjee - sbanerjee@medicine.nodak.edu; Janel Evanson - janel.evanson@und.nodak.edu;

Erik Harris - eharris@medicine.nodak.edu; Stephen L Lowe - stephen_lowe@und.nodak.edu; Robert C Speth - speth@olemiss.edu;

Kathryn A Thomasson - kthomasson@chem.und.edu; James E Porter* - hskerdad@gra.midco.net

* Corresponding author

Published: 06 December 2006

BMC Pharmacology 2006, 6:14 doi:10.1186/147|-2210-6-14

This article is available from: http://www.biomedcentral.com/I47I-22/0/6/14

(c) 2006 Banerjee et al; licensee BioMed Central Ltd.

This is an Open Access article distributed under the terms of the Creative Commons Attribution License (http://creativecommons.org/licenses/by/2.0), which permits unrestricted use, distribution, and reproduction in any medium, provided the original work is properly cited.
Received: 05 December 2006
Accepted: 06 December 2006

\section{References}

I. Banerjee S, Evanson J, Harris E, Lowe SL, Thomasson KA, Porter JE: Identification of specific calcitonin-like receptor residues important for calcitonin gene-related peptide high affinity binding. BMC Pharmacology 2006, 6:9.

\begin{abstract}
This is a correction article.

After publication of this work [I], we became aware of the fact that Robert C. Speth was not included as an author. Dr. Speth put a considerable amount of time and effort into developing and preparing the radiopeptide used to carry out the radioligand binding studies reported in this manuscript and therefore should have originally been included as an author. We apologize to Dr. Speth for any inconvenience that this oversight might have caused and thank him for his invaluable contribution to this project.
\end{abstract}

